\title{
PENDIDIKAN DAN PELATIHAN MEMBANGUN KREATIVITAS DAN KEMANDIRIAN SISWA SMK VIA MEDIKA, CIPUTAT
}

\author{
Ibrahim Bali Pamungkas, Arief Budiyanto, Alvin Praditya, \\ Wahyu Andri Wibowo, Laura Komala \\ Universitas Pamulang \\ Email: dosen01015@unpam.ac.id
}

\begin{abstract}
This activities was entitled Education and Training to Build Creativity and Independence of Via Medika Vocational School Students (SMK), Ciputat. The purpose of this service is to provide direction and guidance to Via Medika Vocational School students, in terms of developing creativity and independence in order to develop their potential. The method of implementing this service is carried out in several stages, namely. 1) Preliminary stages; This stage includes field survey activities and relationships with the object of the service location as well as the preparation of activity designs and outputs from these activities. 2) Socialization Stages; in this stage the team that has compiled and formed the program design then submits it to the school and the implementation and the specified outputs. 3) Stages of implementation; this stage is the implementation of the activity design that has been determined. The conclusion of this service is that students are enthusiastic about carrying out activities that are in self-development so as to generate creativity and independence which ultimately leads to entrepreneurship. The hope of this service activity is that it can open students' insights so that they can further develop themselves, especially in terms of creativity and learning independence. So that it will be able to have an impact both in the family environment, school or community environment in general.
\end{abstract}

Keywords: Training, Education, Creativity, Independence, School

\begin{abstract}
Abstrak
Pengabdian ini berjudul Pendidikan dan Pelatihan Membangun Kreativitas dan Kemandirian Siswa SMK Via Medika, Ciputat. Tujuan pengabdian ini adalah untuk memberikan arahan dan juga bimbingan terhadap siswa SMK Via Medika, hal pengembangan kreativitas dan kemandirian agar dapat mengembangkan potensi diri. Metode pelaksanaan pengabdian ini dilakukan dalam beberapa tahap, yaitu. 1) Tahapan Pendahuluan; dalam tahapan ini meliputi kegiatan survei lapangan dan hubungan dengan objek lokasi pengabdian serta penyusunan rancangan kegiatan dan keluaran dari kegiatan tersebut. 2) Tahapan Sosialisasi; dalam tahapan ini tim yang sudah menyusun dan membentuk rancangan acara kemudian menyampaikan kepada pihak sekolah serta pelaksanaan beserta keluaran yang ditentukan. 3) Tahapan pelaksanaan; tahapan ini adalah pelaksanaan dari rancangan
\end{abstract}


kegiatan yang telah ditetapkan. Kesimpulan dari pengabdian ini adalah siswa antusias terhadap pelakasanaan kegiatan yang bersifat dalam pengembangan diri sehingga membangkitkan daya kreativitas dan kemandirian yang pada akhirnya berujung kepada kewirausahaan. Harapan dari kegiatan pengabdian ini adalah dapat membuka wawasan siswa agar bisa lebih mengembangkan diri terutama dalam hal kreativitas dan kemandirian belajar. Sehingga akan dapat memberikan dampak baik di lingkungan keluarga, sekolah ataupun lingkungan masyarakat pada umumnya.

Kata Kunci: Pelatihan, Pendidikan, Kreativitas, Kemandirian, Sekolah

\section{A. PENDAHULUAN}

Kreativitas dan Kemandirian merupakan hal penting bagi siswa terutama ketika berhadapan dengan perkembangan anak. Banyak penelitian yang menyebutkan bahwa kreativitas dan kemandirian belajar akan berdampak kepada prestasi belajar dan peningkatan diri. Diantaranya yaitu. Nuryani (2013) menyimpulkan dalam penelitiannya bahwa motivasi, kemandirian belajar dan kreativitas berpengaruh positif terhadap prestasi belajar. Prasetyaningsih, Astuti (2014), yang menyimpulkan peningkatan kemandirian belajar akan meningkatkan hasil belajar IPS, dan juga kemandirian belajar akan dapat menurunkan kecemasan belajar siswa menurut (Nurhidayah, 2015), serta penelitian dari (Fatmawati, 2015) yang menyebutkan bahwa terdapat hubungan positif antara kemandirian belajar dengan prestasi belajar walaupun dalam penelitiannya disebutkan hubungan tersebut tidak terlalu signifikan. Sedangkan penelitian yang berkaitan dengan kreativitas antara lain. (Wahyuddin, 2016) menyimpulkan bahwa kreativitas belajar siswa berdampak kepada pemecahan masalah, semakin besar daya kreativitas semakin besar pula kemampuan pemecahan masalah semakin tinggi.

Berdasarkan dari beberapa literasi yang telah disebutkan di atas penting dalam setiap pembelajaran khususnya kepada siswa (pelajar) untuk selalu mengingatkan agar terus mengembangkan kreativitas dan kemandirian belajar dimana hal tersebut diharapkan tidak hanya akan berdampak kepada prestasi belajar tetapi juga self development (pengembangan diri) dari siswa itu sendiri. Dalam artikel kali ini, kita akan membahas mengenai kreativitas dan kemandirian belajar serta beberapa faktor yang berkaitan dengan hal tersebut. Agar dapat dijadikan sebagai khasanah literasi dan keilmuan bagi yang ingin mengembangkan hal tersebut.

1. Rumusan Masalah

Dengan melihat latar belakang yang telah diutarakan di atas, kami berinisiatif untuk melakukan kegiatan Pengabdian Kepada Masyarakat agar dapat membantu dalam hal ini Siswa (pelajar) untuk dapat kenal dengan kreativitas individu serta dapat mengembangkan dan menyimpulkan kemandirian belajar yang diharapkan dapat memberikan dampak khususnya di bidang prestasi belajar serta kehidupan sosial pada umumnya.

2. Tujuan Pelaksanaan

a. Memperkenalkan kreativitas dan kemandirian belajar individu dan yang berhubungan dengan hal - hal tersebut.

b. Mendorong siswa untuk dapat mengaplikasikan teori, model kreativitas serta kemandirian belajar ke dalam keseharian belajar mereka. 


\section{B. METODE PELAKSANAAN}

Metode pelaksanaan kegiatan ini dilakukan dalam 3 (tiga) rangkaian tahapan, yaitu; Pertama tahapan Pendahuluan, Kedua tahapan Sosialisasi dan Ketiga adalah tahapan Pelaksanaan.

Tahapan pendahuluan meliputi kegiatan survei lapangan dan hubungan dengan objek lokasi pengabdian serta penyusunan rancangan kegiatan dan keluaran dari kegiatan tersebut.

Tahapan Sosialisasi; dalam tahapan ini tim yang sudah menyusun dan membentuk rancangan acara kemudian menyampaikan kepada pihak sekolah serta pelaksanaan beserta keluaran yang ditentukan. Dan terakhir adalah Tahapan pelaksanaan; tahapan ini merupakan pelaksanaan dari rancangan kegiatan yang telah ditetapkan.

\section{HASIL DAN PEMBAHASAN}

Pengabdian Kepada Masyarakat (PKM) yang merupakan salah satu Tridharma Perguruan Tinggi adalah sesuatu yang wajib dilakukan oleh setiap Dosen tidak terkecual Dosen dari Universitas Pamulang.

Melalui LPPM (Lembaga Penelitian dan Pengabdian Masyarakat) Universitas Pamulang telah dan akan terus melaksanakan kegiatan Tridharma Perguruan Tinggi termasuk kegiatan Pendidikan dan Pelatihan pada SMK Via Medika, Ciputat ini yang merupakan bagian dari Pengabdian Kepada Masyarakat (PKM).

Dengan adanya kegiatan ini, diharapkan adanya sumbangsih baik itu dalam segi pemikiran, wawasan serta implementasi keilmuan yang dipelajari di Perguruan Tinggi bisa dibawah ke ranah praktis kehidupan.

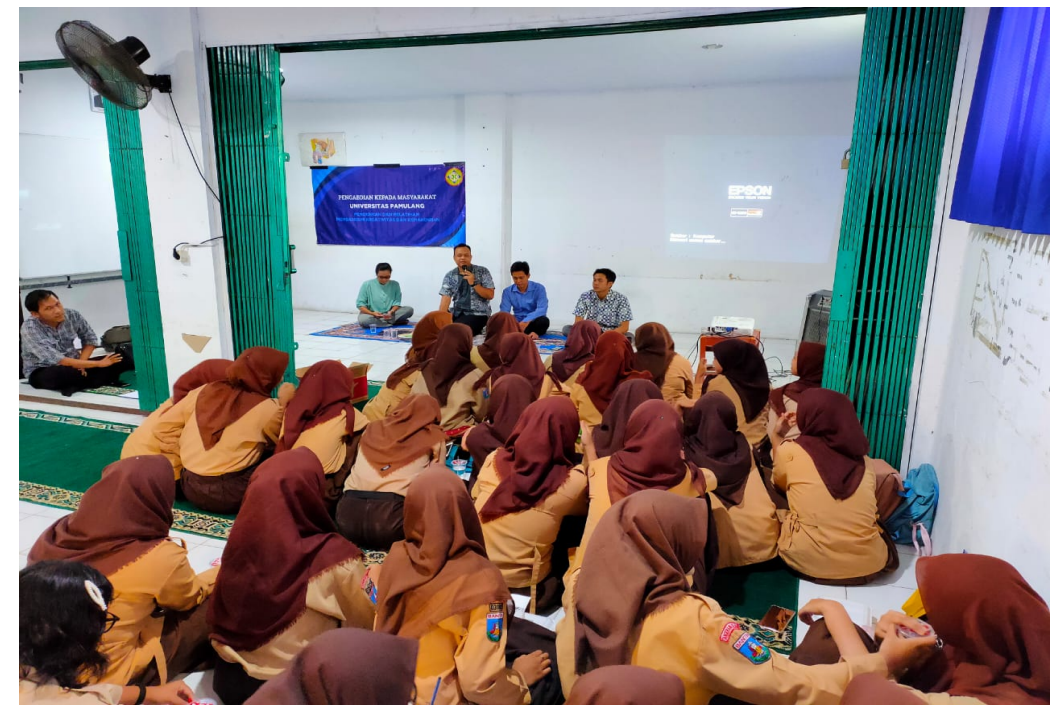

Gambar 1. Penyampaian materi 


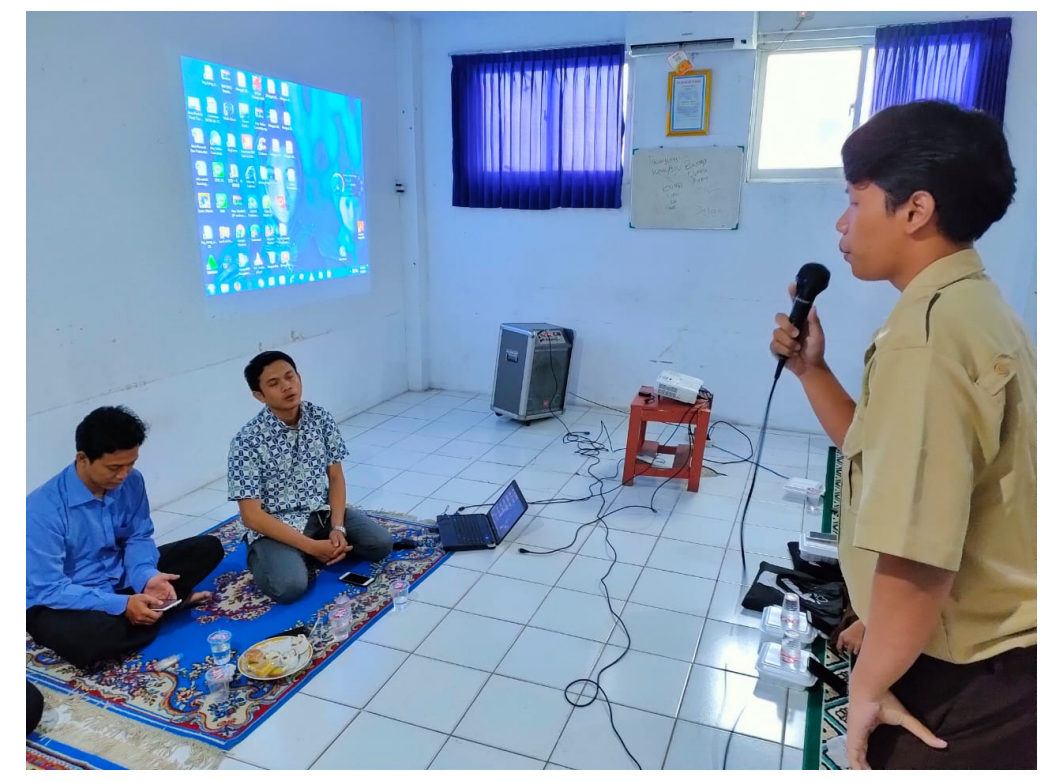

Gambar 2. Pertanyaan peserta

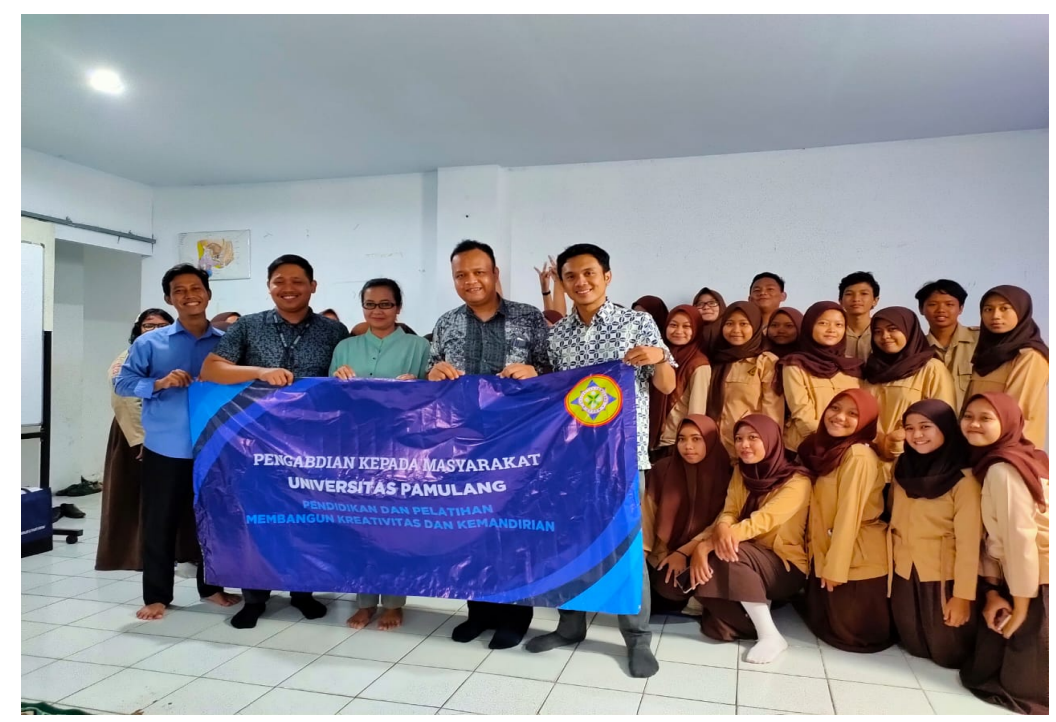

Gambar 3. Foto bersama

\section{KESIMPULAN DAN SARAN}

\section{Kesimpulan}

Siswa dapat memahami materi dan pemaparan yang diberikan oleh pemateri beserta dengan pengembangannya. Adanya permintaan dari pihak sekolah untuk rutin mengadakan kegiatan Pendidikan dan Pelatihan bisa dijadikan sebagai acuan bahwa kegiatan pengabdian yang dilakukan ini mendapatkan respon positif dari pihak objek pengabdian.

\section{Saran}

Dalam penyusunan acara kedepannya lebih diperhatikan terkait dengan jam belajar agar tidak mengganggu waktu belajar yang sudah ditentukan oleh sekolah. Materi yang disampaikan dibuatkan kertas kerja (worksheet) MONEV (monitoring \& evaluation) yang 
berguna agar siswa dapat secara individual mengukur keberhasilan dari kegiatan Pendidikan dan pelatihan.

\section{DAFTAR PUSTAKA}

Armiati. (2011). Strategi Mewujudkan Sekolah Kejuruan Berbasis Kewirausahaan Dalam Peningkatan Kemandirian Dan Kreatifitas Siswa Melalui Koperasi Sekolah. Tingkap, 2, $147-160$.

Dumilah, R., Sunarto A., Ahyani, Solihin, D., Maulida H. (2020). Pelatihan Pemanfaatan Media Sosial Untuk Promosi Usaha Atau Bisnis Bagi Siswa. DEDIKASI PKM. Vol. 1. No. 1.

Fatmawati, S. (2015). Hubungan Sikap Dan Kemandirian Siswa Terhadap Prestasi Belajar. Oikonomia - Jurnal Pendidikan Ekonomi, 24-27.

Jumaisyaroh, T., \& Hasratuddin, E. E. N. (2015). Peningkatan Kemampuan Berpikir Kritis Matematis Dan Kemandirian Belajar Siswa Smp Melalui Pembelajaran Berbasis Masalah. 5(1), 88 .

Nurhidayah, S. Dkk. (2015). Konsep Diri Dan Kemandirian Dengan Kecemasan Pada Siswa Kelas X Dan Xi. Soul; Jurnal Pemikiran Dan Penelitian Psikologi, Vol. 8(No. 1), 6-8. Https://Doi.Org/10.16309/J.Cnki.Issn.1007-1776.2003.03.004

Nuryani, A. Dkk. (2013). Pengaruh Motivasi Berprestasi, Kemandirian Belajar Dan Kreativitas Terhadap Prestasi Belajar Ekonomi Siswa Kelas Xi Ips Sma Muhammadiyah Di Kabupaten Karanganyar Tahun Pelajaran 2012/2013. Jurnal Pendidikan Insan Mandiri, 1(1), 15-29.

Prasetyaningsih, Astuti, D. (2014). Hubungan Kemandirian Belajar Dan Interaksi Edukatif Dengan Hasil Belajar Ips Siswa Kelas Iv Sd Sekecamatan Purworejo. Kalam Cendekia Pgsd Kebumen, 2(3).

Ricky W. Griffin. (2013). Management (Eleventh E). South Western: Cengage Learning.

Stephen P. Robbins, David A. Decenzo, \& Mary Coulter. (2013). Fundamentals Of Management: Essentials Concepts And Applications (8th Edition). Retrieved From Www.Mymanagementlab.Com

Wahyuddin. (2016). Pengaruh Metakognisi, Motivasi Belajar, Dan Kreativitas Belajar Terhadap Kemampuan Pemecahan Masalah Siswa Kelas Viii Smp Negeri 2 Sabbangparu Kabupaten Wajo. Jurnal Daya Matematis, 4(1), 72-83. 